\title{
A construção do corpo ideal no balé clássico: uma investigação fenomenológica
}

CDD. 20.ed. 792.8

793.3

http://dx.doi.org/10.1590/1807-55092015000300439
Kátia Silva Souza dos ANJ OS*

Régia Cristina OLIVEIRA* Marília VELARDI ${ }^{*}$
*Escola de Artes, Ciências e Humanidades, Universidade de São Paulo.

\section{Resumo}

0 objetivo deste trabalho foi identificar e compreender pela perspectiva das bailarinas participantes do estudo o ideal de corpo demandado pela prática do balé. Para tanto, optamos por uma orientação epistemológica apoiada na fenomenologia de Edmund Husserl e em autores afinados com a fenomenologia proposta por esse filósofo. As entrevistas semiestruturadas em profundidade constituíram a técnica de pesquisa utilizada. 0 que há de comum nas falas das bailarinas é a referência a um corpo ideal centrado nas produções feitas pelas grandes companhias de balé. Nessas percepções, o corpo desejado e ideal para o balé clássico pode ser tanto inato à pessoa, quanto construído e transformado com muito esforço e dedicação pela bailarina.

PalavRas-Chave: Vivência; Corpo; Fenômeno; Balé; Expressão corporal.

\section{Introdução}

O presente trabalho é resultado de indagaçóes iniciadas pelas pesquisadoras, uma delas como professora de balé, bailarina e pesquisadora e as outras como pesquisadoras no campo da sociologia do corpo, da corporeidade e do corpo nas artes. Em cada uma das vivências das autoras, os sentidos atribuídos ao corpo comuns à prática artística pode trazer à tona um conjunto de ressignificaçóes sobre os sentidos do corpo noutras vivências que não aquelas típicas da arte. $\mathrm{O}$ interesse pelo tema e a construção do problema de pesquisa surgiu, portanto, dessas experiências subjetivas e a sua materialização, além de responder questôes próprias da pesquisa, apontam para reflexões existenciais.

Para quem estuda e também para aqueles que vivem especialmente a prática do balé, seja como professores, coreógrafos ou bailarinos, é notória a preocupação com o biótipo magro e com a conquista da magreza, ainda que a custas de sacrifícios. A imposição do corpo magro transforma em conquista a perda de alguns gramas, especialmente se conseguida às vésperas das apresentações dos espetáculos ou das provas de passagem de nível de formação, de modo particular para bailarinos em vias de profissionalização.
O balé clássico é uma arte secular, uma dança permeada de histórias idílicas e amores "românticos". Segundo CAMINADA ${ }^{1}$, trata-se de uma modalidade de dança com técnica específica que remonta séculos, mais especificamente o século XVII, quando o balé tornou-se acadêmico havendo, então, sistematização do ensino, com regras corporais e uma nomenclatura própria (p.105). Dentre as características esperadas da bailarina destaca-se a verticalidade corporal mantida pela noção de eixo alinhado à coluna vertebral e por um corpo magro e leve, forçando uma determinada conduta estética. Como aponta CAminadA ${ }^{1}$, o balé "surgiu e foi encenado com a finalidade não só de entreter a corte, mas para mostrar a essa mesma corte e aos países estrangeiros a força da realeza e o poder econômico da França"(p.105).

CAminadA $^{1}$ apontou que o balé tornou-se clássico quando o "ballet" de corte completou um século de tradição e de regras imutáveis. Todavia, dada a dificuldade de um trabalho técnico em virtude dos adornos comuns da época (roupas pesadas, perucas etc.), são os bailarinos "acadêmicos" que, aos poucos, vão modificando as vestimentas e os movimentos, trazendo a técnica corporal para o centro das atençôes (p.116). 
Interessante notar que o balé romântico traz à tona o corpo exigido da época quando da encenação de grandes obras como La Sylphide apresentado em Paris no século XIX, considerado o marco inicial do balé romântico ${ }^{2}$. Esse trabalho foi encenado por Marie Taglione, que foi vista como a própria imagem da sílfide: magra e franzina, capaz de personificar a fragilidade e leveza da personagem título (p.102). De acordo com $\mathrm{MourA}^{2}$, a idealizaçáo da mulher no período romântico era a de uma mulher pálida, frágil e doente, pois os românticos achavam a tez pálida uma forma de exibir a pureza da alma (p.103). Esse novo tipo de balé, que praticamente expunha a idealização feminina esperada pela sociedade da época, ainda perdura na atualidade, visto que os grandes balés de repertório são encenados até hoje e requerem quase o mesmo biótipo do passado, ainda que as exigências em relação ao condicionamento físico acrescentem à magreza a quase obrigatoriedade do desenvolvimento muscular o que resulta na formaçáo de bailarinas magras, porém com estrutura física forte.

Essa lógica de exigência de certo biótipo da bailarina permanece no ensino e na prática do balé e na montagem do repertório tradicional por companhias e escolas de dança. Para as bailarinas, dançar balé de repertório, um grande balé, é um marco importante, tendo em vista representar o auge de uma bailarina - sua consagraçáo entre os pares. Mas, para que ela consiga chegar a esse nível, muito precisa ser feito. Segundo argumentam as bailarinas entrevistadas é fundamental que a bailarina tenha um corpo considerado apropriado e técnico, o que lhe garante uma prontidão para a representação dos papéis mais importantes que possam surgir. Todavia, mais do que lidar com questóes objetivas referentes à modalidade técnica, o percurso que leva à constituição do que é ideal para que a bailarina

\section{Método}

Tendo em vista o problema de pesquisa que orientou a investigação - os sentidos atribuídos pelas bailarinas ao corpo requerido pelo balé clássico - utilizou-se a investigação qualitativa orientada pela fenomenologia ${ }^{a}$. Como técnica de pesquisa, foram realizadas entrevistas semiestruturadas em profundidade com bailarinas clássicas.

Antes de discorrer sobre as entrevistas, faz-se necessário abordar a fenomenologia, ressaltando sua pertinência na compreensão de questóes relativas ao campo da atividade física. possa dançar um balé de repertório pode ser pensado como um percurso de vida, uma vez que exige sacrifícios e dedicaçáo de muitos anos, como mostram as entrevistadas.

No referente a esse aspecto, MourA ${ }^{2}$ salienta que ao longo da história do balé clássico observa-se a exigência de regras rígidas referentes à estética corporal; a um padrão de corpo desejável para a bailarina, tanto para aquelas que são profissionais, quanto para as diletantes (p.9).

No interior desse cenário de exigências técnicas e de padrôes corporais, os sentidos das vivências apresentados pelas bailarinas evidenciam formulaçóes subjetivas em relação ao ideal de corpo e àquilo que é necessário para atingi-lo, e que o presente texto busca discutir.

Interessa, assim, entender esse ideal de corpo pela percepção de quem vivencia essa demanda. Nosso objetivo, entáo, é identificar e compreender pela perspectiva das bailarinas o ideal de corpo demandado pela prática do balé. Para tanto, apoiamo-nos em Husserl e autores afinados com a fenomenologia.

Cabe aqui declararmos aquilo que nos aponta MoreirA ${ }^{3}$, para quem "o ser humano não aprende somente com sua inteligência, mas com seu corpo e suas vísceras, sua sensibilidade e sua imaginação" (p.140). Nessa perspectiva, considera-se que a relação com o mundo pode ser apreendida através da fala, da expressão de cada sujeito, das singularidades e de suas vivências. Mais do que afirmar que existe um corpo adequado ao balé, a preocupação deste texto é discutir o sentido desse fato, pela perspectiva das bailarinas e não o fato em si. Conforme aponta Ales Bello 4 "Husserl diz, por exemplo, que não interessa o fato de existir, mas o sentido desse fato", assim, segundo a autora, é permitido a nós " 'colocar entre parênteses' a existência dos fatos para compreender sua essência” (p.23).

A fenomenologia, segundo Ales Bello ${ }^{4}$, é composta por duas palavras de origem grega - fenômeno, significando "aquilo que se mostra", não só o que parece ou aparece, ou seja evidencia um ato, mas aquilo que é mostrado e que será percebido por alguém (p.17). Assim, o ato de ver é identificado como algo que possibilita a existência do fenômeno.

A segunda parte do termo, logia, do termo grego "logos", é utilizada por Ales BeLLo ${ }^{4}$ na sua acepção como pensamento, como capacidade de reflexão. 
Desse modo, a fenomenologia seria a reflexão sobre aquilo que se mostra, ou seja, o fenômeno (p.18).

Como desenvolve a autora, o fenômeno mostra-se a nós, seres humanos, e isso é crucial para a compreensão da fenomenologia, pois, segundo esta perspectiva, a pessoa humana percebe a existência das coisas pela capacidade sensorial que nos constitui, mas a pessoa busca o sentido/significado dessas "coisas" que não são, necessariamente, "coisas" físicas, mas também relativas ou à cultura, ou ao conjunto de situaçóes.

Para a compreensão do fenômeno, Ales Bello ${ }^{4}$, apoiada em Husserl, ressalta a necessidade de um caminho, compreendido como método. $\mathrm{O}$ termo "método" também é formado de duas palavras de origem grega: "odos" que significa estrada, caminho; e "meta”, por meio de, através (p.21). Segundo Husserl, citado por Ales Bello, o caminho teria duas etapas. A denominada de Redução Eidética, que é a identificação da essência ${ }^{\mathrm{b}}$ pelo sentido da coisa. Assim, devemos nos conduzir à estrutura fundante da coisa e "colocar entre parênteses" a existência dos fatos, porque o que interessa nesse processo é o sentido. Para Husserl, segundo Ales Bello ${ }^{4}$, o ser humano consegue apreender o sentido de muitas coisas, porém, algumas são mais difíceis de serem compreendidas (p.23).

A segunda etapa do método é a Redução Transcendental. Aqui entramos no campo das vivências do sujeito. Pelo ato perceptivo tem-se o acesso ao sujeito: o registro dos atos é feito pela consciência e essa consciência dos atos são vivências.

Ao se optar pelo estudo do ideal de corpo numa dada modalidade de dança, o que justifica esse "ideal de corpo" ser considerado um fenômeno é o próprio fato: a existência clara desse ideal apontada naquilo que Ales Bello ${ }^{4}$ descreveu como as ciências do espírito, como, por exemplo, a Sociologia e a História (p.15). Nesses campos teóricos, tem-se a evidência de que o corpo humano é moldado culturalmente. O Ideal de corpo é um fenômeno, pois se percebe que em cada sociedade, com suas práticas corporais, suas crenças e valores, haverá um corpo "necessário" para a pessoa ser considerada integrante do meio em que vive.

Basear-se na fenomenologia como método nos permite descrever e compreender a complexidade do fenômeno em estudo. Como argumenta BARreIrA ${ }^{5}$ "é neste sentido que a complexidade dos fenômenos relacionados ao lidar com a corporeidade, sobretudo no que se refere às práticas de atividade física, ganhariam em se abster da dependência da mentalidade médico prescritiva voltando-se anteriormente a pesquisas de ordem descritivo-compreensiva”(p.3). Como sugere o autor supracitado, "as ciências da atividade física têm, como se propóe aqui, o método fenomenológico como modo pertinente de estudo daquelas dimensóes existenciais situadas em relação ao corpo em movimento que [...], colhem e projetam horizontes de vida que condicionam a relação com a corporeidade, seja ela reificada, ativa, esquecida, transcendente"(p.4).

BARREIRA $^{5}$ apoia-se em Husserl para afirmar que a fenomenologia parte de um "valor cognitivo intermediário" para o alcance desse conhecimento primeiro, sendo que esse valor intermediário, no caso da atividade física, "pode estar desde a denominação da prática investigada (judô, atletismo, escalada, futebol, etc.), a qual já pressupóe um conteúdo específico, até as múltiplas formas de coleta de dados, como a observação, a participação e a entrevista aberta em profundidade"(p.7).

Assim, por esse caminho, não se busca uma generalização dos significados dados às dimensóes existenciais, pois o fenômeno será apreendido de maneira intermediária, ou seja, existirá uma determinada prática, um espaço específico e vivências singulares provenientes de experiências muitas vezes comuns, mas que denotam o recorte do fenômeno estudado.

Em outro texto, BARREIRA et $a .^{6}$ ressalta a atividade física como um campo passível de ser estudado em várias facetas, não precisando ficar exclusivamente alocada na área das ciências naturais que utilizam técnicas que visam estabelecer uma causalidade deixando de lado aspectos da prática efetiva, "vivida em primeira pessoa"(p.4). Esse autor ainda aponta que se deve "frisar que a filosofia fenomenológica de Husserl não se opóe nem se indispóe com a precisão deste modelo físico e deste conhecimento, acertado em seus procedimentos. Sua oposição e indisposição se dirigem ao fato de torná-lo um referente absoluto" (p.4).

Para BArreira et al. ${ }^{6}$, o acesso à experiência pessoal nesse tipo de investigação norteia a busca pelo significado do fenômeno e, assim, a entrevista é sugerida como técnica. "A entrevista fenomenológica visa seu preenchimento e, para isso, aprofunda o esclarecimento mútuo entre pesquisador e colaborador, colocando questionamentos que se dirijam à experiência pessoal, rumo à experiência própria e fundadora"(p.5); rumo à um aprofundamento no humano, na pessoa que vive "a coisa", fazendo emergir daí reflexôes e não relaçôes causais e, assim, possibilitando um outro modo de se enxergar a realidade.

Uma das tarefas que exige uma reflexão constante do pesquisador é o cuidado em manter a atitude fenomenológica desde o início. Aí está pressuposta uma "atitude filosófica" (problemática), diferente 
da "atitude natural", vista como ingênua ${ }^{7}$ (p.23); um retorno às coisas mesmas, que se faz necessário durante toda a pesquisa.

Baseada nessas orientaçóes foi feita uma síntese para cada entrevista, destacando-se os elementos de análise e as características particulares de cada entrevista. Nessas sínteses, evidenciam-se os correlatos da atitude pessoal que são significativos para a pessoa. $\mathrm{O}$ que importa, em termos da fenomenologia, é como a pessoa narrou a relação dela com o objeto de pesquisa, o corpo do balé. Na investigação realizada, as entrevistas foram assim descritas: a letra B significa bailarina, os números indicam a ordem em que as entrevistas foram feitas. Entrevista B1 realizada em 26 de agosto de 2009 numa sala dentro de um "campus" universitário. Essa bailarina tinha por volta de 20 anos de idade; B2 realizada em 26 de agosto de 2009, dentro de um "campus" universitário, porém, em outro local, a bailarina tinha 30 anos de idade e atuava como professora de balé; B3 realizada em 23 de julho de 2010, a bailarina tinha 22 anos de idade e atuava como bailarina e professora de balé, o local da entrevista foi a casa da bailarina; B4 realizada em 21 de fevereiro de 2011, a bailarina tinha 50 anos de idade e atuava como professora de balé. Esta entrevista foi feita no estúdio de dança onde a pessoa ministrava aulas; B5 realizada em 1 de março de 2012, a bailarina tinha 42 anos de idade e atuava como professora de balé; a entrevista foi feita em seu estúdio de dança; B6 realizada em 6 de março de 2012; a bailarina tinha 27 anos de idade e atuava como professora e bailarina; a entrevista foi feita no estúdio de dança onde ministrava suas aulas.

Foram feitas seis entrevistas ${ }^{c}$ semiestruturadas em profundidade $^{\mathrm{d}}$. Na primeira entrevista, a conversa fluiu, e já foi possível vislumbrar o fenômeno, uma vez que a pessoa conseguiu falar e refletir sobre sua vivência, o que para o entrevistador é algo rico; a segunda entrevista também aconteceu de forma intensa, a pessoa rememorou situaçóes que a emocionaram, declarando profundo envolvimento com as suas vivências; já a terceira entrevista apresentou um problema: a entrevistadora saiu da atitude fenomenológica e usou de informaçóes das outras entrevistas para conduzir a conversa, assim, o que se obteve foi um discurso vazio, carregado de teorias já colocadas pela entrevistadora. Porém, ao ler essa entrevista e notar o erro, a entrevistadora descartou essa entrevista, uma vez que tinha se distanciado da orientação clara que nos dá a ideia da "epoché" - de suspensão, do retornar às coisas mesmas, sem teorias prévias, retendo-se ${ }^{8}$ (p.76). Nessa terceira entrevista a pessoa não foi como as outras duas entrevistadas, que eram mais falantes e não tinham receio de relembrar as suas vivências. Para essa terceira entrevistada nós, provavelmente, precisaríamos de mais tempo ou de outra abordagem de entrevista. Realizamos, então, outra terceira entrevista e, nesta, a conversa aconteceu sem problemas, na casa da entrevistada, num ambiente favorável, tranquilo, para a reflexão.

$\mathrm{Na}$ entrevista 4 e 5 tudo correu bem, as entrevistadas eram duas mulheres maduras que falaram com muita tranquilidade e fluência. A última entrevista, a sexta, quase não fluiu, porém, a entrevistadora, já mais consciente de sua atitude e atenta à ideia do "epoché", conseguiu estimular a entrevistada para a manifestação das suas vivências e, ao terminar a conversa, a entrevistadora compreendeu o porquê do quase não retorno da entrevistada à sua vivência, pois ela mencionou que existem coisas que gostaria de esquecer, deixando clara a natureza do impacto das suas vivências. Todavia, em nenhum momento ela interrompeu a entrevista, mesmo tendo sido informada dessa possibilidade. Também não chorou. Foi uma entrevista curta, porém, rica de sentido, dado pelo seu contexto.

$\mathrm{O}$ processo da pesquisa nos conduziu à compreensão das "etapas" do método de uma forma conjunta. Assim, a "epoché", a reduçáo eidética e a reduçáo transcendental náo aconteceram por etapas. Tais procedimentos já correspondiam à atitude fenomenológica desde o início da pesquisa.

Fazendo parte do método fenomenológico ${ }^{\mathrm{e}}$, a redução transcendental remete-nos, em termos de compreensão, às palavras que a compõem. A primeira - redução - de acordo com Goto $^{8}$, adquiriu na fenomenologia o sentido de recondução ao que o autor denomina de "resíduo fundante" (p.79), e que compreendemos como essência. Assim, tem-se a suspensão daquilo que é individual e contingente ("epoché"). Foi o que se procurou realizar nesta pesquisa. Nas sínteses das entrevistas ainda aparecem as características individuais das entrevistadas, mas no cruzamento intencional realizado, procurou-se exaltar aquilo que é universal nas falas. Destarte, nosso olhar foi para o fenômeno estudado : o ideal de corpo do balé clássico.

A segunda palavra, transcendência, para HuSSERL ${ }^{9}$ possui dois sentidos, focalizamos em apenas um, o qual sugere que o objeto de conhecimento pode não estar contido cognitivamente enquanto algo real, e sim no que o ato de conhecer busca e possibilita perceber e recordar; o objeto, ou a coisa, está no ato enquanto vivência, ou seja, a transcendência nesse sentido é "aquilo que está imanentemente incluso enquanto vivência cognitiva"(p.60). TourinHo ${ }^{10}$ 
aponta que, para Husserl, a redução transcendental ${ }^{\mathrm{f}}$ é o próprio domínio do conhecimento (p.5). A transcendência e a imanência inicialmente são pensadas como antagônicas, sendo a primeira entendida como o "estar fora da pessoa" e a segunda como o "estar dentro", mas a redução transcendental vai além, e a transcendência e a imanência serão compreendidas numa mesma escala - "uma transcendência na imanência”. Assim, compreendemos que há uma relação evidente entre o sujeito (que vivencia) e o objeto (vivenciado e constituinte da consciência) ${ }^{10}$ (p.10). No subjetivo encontramos a objetividade.

A partir das entrevistas com as bailarinas procuramos, por meio da "epoché", da redução eidética e da redução transcendental, responder nosso objetivo, compreender, pela ótica das bailarinas, qual é o corpo demando pela prática do balé e como ele é apreendido

\section{Resultados e discussão}

\section{As unidades do sentido}

Pelo discurso das entrevistadas fica claro que existe um corpo ideal para o balé clássico. Os relatos transcritos nos conduziram à identificação de cinco US que delinearam nossos resultados sobre o ideal de corpo demandado pelo balé. Por unidade entendemos algo que é único, unido; e é assim que compreendemos os resultados, pois as unidades, por mais que apareçam separadas na descrição, são vistas como indivisíveis. Isso possibilita a compreensão do fenômeno em dois sentidos: como algo que é unicamente voltado para o fenômeno ora estudado, sem generalizaçóes, e que o pensar não se dá simplesmente categorizado, mas ocorre numa confluência. As US encontradas a partir dos relatos transcritos foram: fatalismo da determinação, a tríade do corpo da bailarina, eficiência e funcionalidade corporal, moralidade da dedicação e imitação prestigiosa e profissionalização no balé. Assim, foram cinco as US, porque esse foi o nosso olhar para os relatos. As falas que ajudaram a nomear tais unidades foram as que surgiram com mais recorrência. A cada leitura, em cada entrevista, essas unidades eram fortalecidas e é isso que apontamos nos resultados, exaltando as próprias falas, em cada unidade.

\section{Fatalismo da determinação}

No balé clássico, o padrão de corpo ideal é veiculado pelas instituiçóes consideradas responsáveis pelas bailarinas. O objetivo possui dois verbos que se relacionaram com as duas reduçóes, primeiro o "identificar" o ideal de corpo, que nos remete a redução eidética (essência) e o segundo verbo "compreender" esse ideal, sugerindo a redução transcendental cujo entendimento do fenômeno se dá por meio da intersubjetividade, da relação do sujeito com o objeto.

Após a realização das entrevistas e de suas transcriçôes, partiu-se para a leitura desse material e já nas sínteses apareceram elementos que compuseram as unidades de sentido do fenômeno, as quais tornaram possível uma melhor compreensão do significado, para a bailarina, do ideal de corpo para o balé. Essas unidades de sentido (US), que dizem respeito ao cruzamento intencional dos discursos, permitiram às pesquisadoras a contextualização da experiência vivida pelas bailarinas ${ }^{\mathrm{g}}$. E assim chegamos aos nossos resultados.

pela ascensão da bailarina ao universo profissional. Nesse campo, os critérios para ser uma bailarina são oriundos das grandes companhias de balé. O corpo requerido nesse universo é fundamental, pensado com vistas ao progresso no aprendizado e, para a bailarina, não é possível evitar aquilo que já foi determinado pela cultura do balé e veiculado pelas reconhecidamente melhores companhias do mundo.

Nas falas, os festivais de dança e as audiçóes são apontados como os locais de veiculaçáo do padrão de corpo requerido e as referências internacionais, que são assistidas sistematicamente em vídeo ou presencialmente, são mencionadas como as ideais.

Duas entrevistadas tiveram vivências fora do Brasil e relataram a imposição da magreza para que elas continuassem nesses locais.

A entrevistada $\mathbf{B} 6$ relata:

Lá (Alemanha) eles têm uma linha de trabalho, a partir do momento que eu cheguei na escola, toda sexta-feira, não sei se hoje em dia é assim, mas na sexta-feira era o dia da balança, então as pessoas que têm bolsa dentro da escola não podiam engordar.

Destacando a centralidade da manutenção de um determinado peso, considerado ideal, no balé clássico, bem como, a existência de um controle sobre as bailarinas que, como a entrevistada, tinham bolsa para os estudos e, com base nesse critério, eram ainda mais cobradas para que mantivessem um peso considerado ideal. Outra entrevistada, B3, reforça 
essa ideia, e acrescenta o fato de que o controle do peso é uma condição para a manutenção da bolsa. Como destaca:

é preciso ser magra: Eu era bolsista lá (Itália) e como bolsista ela falava - você sabe que se você engordar um grama, você pode perder a bolsa entáo ela já deixava claro que tem que ser magra.

A experiência pessoal de estudar fora do país, acompanhada de outras vivências possibilita a reflexão, como revela a entrevistada B2:

Já tive experiências de alunos que fizeram várias audiçóes e cada aluno tem um corpo, um físico e, eu, a gente tem nitidamente essa diferença. Os alunos do físico padrão mesmo do balé, que é pedido aquele físico esguio, longilíneo, magro, são os que mais têm respostas e retorno de prêmios e trabalhos.

Como menciona Moura ${ }^{2}$, "às bailarinas clássicas exigia-se - como se exige até hoje, um corpo magro (até mesmo esquelético), longilíneo, sem muitas curvas que denunciassem a mulher dentro do $t u t u$ "h (p.9). Outra característica apontada por Moura $^{2}$ é em relação ao biótipo requerido que corresponde ao padrão euro-americano de corpo (p.18). A existência de um corpo ideal no balé clássico é mencionada pelas bailarinas, conforme apontam:

B1: Eu acho que existe (corpo ideal) dentro das características das companhias que a gente vê hoje. Sempre foi muito cobrado nos festivais que eu tivesse dentro de um peso e os próprios treinos.

B4: Mesmo que eu não dance, só de você assistir aos vídeos recentes de dança você vê, uma mudança tamanha que a gente consegue ter a leitura.

B5: No balé clássico em específico claro que existe alguns pré-requisitos, fisicamente falando.

Fica claro que para ser uma bailarina, "ter e apresentar um corpo" de acordo com os padróes requeridos, é algo inevitável. Esse biótipo requerido implica forma, eficiência e determinada estética. $\mathrm{O}$ corpo magro e a magreza são o cerne da questão, em torno do qual a técnica ${ }^{i}$ deve ser instituída. Como define MAuss ${ }^{11}$, as técnicas corporais são "maneiras pelas quais os homens, de sociedade em sociedade, de uma forma tradicional, sabem servir-se de seus corpos"(p.211).

No caso da bailarina, a técnica relaciona-se aos movimentos apropriados do corpo; à sua redefinição, ou, ao menos, à aproximaçáo do "corpo ideal" próprio do balé clássico.

\section{A Tríade do corpo da bailarina: anatomia, técnica e expressão}

O corpo ideal para o balé é magro, sem curvas, longilíneo, com membros alongados e finos. Como destaca Moura ${ }^{2}$, o que se espera de uma bailarina é:

(...) que apresente um corpo que corresponda ao estereótipo de bailarina romântica européia do século XIX: que seja uma sílfide ou uma fada mesmo quando não anda nas pontas. Que seja leve, graciosa, magra e longilínea. E que essa menina mantenha a aparência jovem pelo tempo que for possível. E que - caso o destino ou o código genético náo a tenham equipado para tal - tenha suficiente disciplina e determinaçáo para mudarem o que for preciso a fim de encaixarem no modelo, a qualquer custo" (p.18).

As bailarinas entrevistadas destacam esses aspectos, ressaltando ainda a necessidade de especial flexibilidade em determinadas partes do corpo, como pés, pernas, coxas e joelhos:

B1: Então, com o avanço do balé clássico, há uma preocupação de você ter um físico belo, hiperextensão de joelho, ser magra enfim.

B5: Ela tem que ter uma rotação de coxo femoral muito interessante, ela tem que ter uma excelente flexibilidade.

B2: Sim, eu conseguia dentro do meu padrão, meu corpo, eu conseguia desenvolver coisas até além dos limites pelo corpo que eu tinha, porque eu não tinha o físico esguio.

B3: Eu acho que para o balé clássico, no meu caso tem que ser magra, tem que ter uma linha, se for mais gordinha não encaixa tanto no papel. B4: O biótipo no sentido da forma. Bacia estreita, longilínea. Uma proporçáo física, facilidade pra ser magra eu era um pessoa que náo engordava, náo precisava fazer, só com o trabalho eu já era, eu ficava super alongada, um físico leve. B6: Lógico que o ideal seria uma bailarina do tipo magra.

Apoiada nessas condiçóes, tem-se que a mecânica dos movimentos do balé é bem restritiva. Desse modo, o indivíduo que não possuir extrema facilidade para atender a essa mecânica, deve construí-la e procurar beneficiar-se de outras qualidades que seu corpo deve possuir, como por exemplo, a técnica. Uma característica marcante da mecânica dos movimentos do balé é a rotação externa dos membros inferiores, o "en dehors"; todos os passos do balé são 
realizados com os membros inferiores em rotação externa e essa pode ser construída. Algumas pessoas já possuem a anatomia da articulação coxofemoral favorável para tal posicionamento, outras terão que "trabalhar muito" para conseguir esse padrão, como as entrevistadas disseram, sendo que essa rotação é de extrema importância para o sucesso no balé clássico. Contudo, além desse corpo magro, que é a "essência" - e nossa primeira esfera para compreender a "tríade" - a pessoa deve adquirir a técnica própria do balé, que é a segunda esfera da construção do corpo ideal, segundo a percepção das bailarinas, porém, essa é subordinada à anatomia. Essa estética corporal do balé é bem definida e aparece como algo extremamente necessário para o sucesso da bailarina.

B1: O corpo ideal para mim, se conseguir juntar o físico de hoje em dia que é proposto, com a técnica clássica; não adianta você ter só o físico ou só a técnica, se você conseguir aliar os dois você vai ter o físico que as pessoas procuram.

Além da anatomia e da técnica existe outra esfera importante, a da expressão, reportada por quase todas as entrevistadas como algo que veem como inato à bailarina; espécie de "sensibilidade própria” à bailarina. Esse elemento é reconhecido como aquele que define o balé enquanto arte e não somente como uma prática performática análoga ao esporte de alto rendimento. Porém, para as entrevistadas, a arte emerge da vivência da bailarina que, ao se deparar com a execução de um balé de repertório, ou com um balé que possua um enredo, ela representa um papel. É aí que a performance motora se transforma em arte. $\mathrm{O}$ uso do verbo “ser", nesse caso, aponta para uma dimensão existencial distinta daquela que foi declarada anteriormente com o uso do verbo "ter", referente ao corpo. Esse último, o "ter", evidencia o caráter externo da técnica de construção do corpo ideal, enquanto o primeiro, "ser", aponta para a "naturalização" da arte cênica, segundo a percepção das entrevistadas; do corpo enquanto "ser", referido à expressáo da arte cênica e pensado como próprio a algumas bailarinas que, então, apresentariam um "dom" para a arte de representar. Essa percepção das bailarinas remete, por um lado, à discussão de LE BRETON $^{12}$ sobre a separação corpo-pessoa nas sociedades contemporâneas ocidentais, dada por meio da subutilização do corpo e pela desvinculação do corpo, tanto da pessoa, quanto do mundo que o cerca. A experiência no mundo não estaria mais sendo dada por meio do corpo, que se separa do sujeito; o corpo visto quase como um alter ego da pessoa.

Num caminho inverso, as bailarinas entrevistadas parecem retomar a articulação corpo-pessoa por meio da expressão corporal; da valorização dos sentidos e expressóes, por meio do corpo. Todavia, para as bailarinas entrevistadas, o "ser" no corpo, da arte de representar, aparece como algo inato, próprio a cada uma. Para a compreensão sócio-antropológica do corpo $^{13}$, ainda que as sensaçóes e expressóes sejam percebidas como próprias "do" indivíduo e, de fato, haja esta dimensão pessoal, há outra dimensão que a ela sempre se articula e que nos escapa, e que diz respeito ao caráter social das emoçóes, dos sentimentos e de suas expressóes, não sendo os mesmos, portanto, "naturais", ainda que assim nos pareçam.

Além da percepção dessa naturalização pelas bailarinas, há também uma associação da técnica de interpretação com o tipo de tônus muscular requerido e do ritmo da música, que tendem a induzir "naturalmente" a gestualidade expressiva. Isso fica bastante evidente na fala de uma das entrevistas;

B5: Você passa por um adágio, você passa por um "allegro", você passa por uma valsa, moderato, uma polca que são os vários ritmos que possibilita você trabalhar um condicionamento técnico para efetivar, ativar alguns grupos musculares, e afinar, alongar, é agilidade e tem dinâmica; mas é aonde você também incorpora o lado artístico - gente o adágio uma coisa mais fluída.

Noutras falas, a ideia é de sensação e emoção, o sentir e o emocionar, como norteadores da ação física de representar, o que permite que a interpretação seja encarada como o ato de reproduzir o que o texto pede, o personagem, retirado do balé de repertório, sendo executado conforme as características descritas no enredo. Como descrevem

B6: Eu acho que o lado artista, as pessoas nascem, pode ser construído? Pode. Mas eu acho que é diferente quando a pessoa nasce com esse sentimento, sentir a música.

B3: Tem que dançar, tem que vir de dentro, você não pode ser falso, porque você tem que ser atriz, porque você tá interpretando um papel, só que se você é falso você passa isso para a plateia e ainda mais balé, o povo assiste ou fala - ai que ruim, que coisa feia.

Na percepção da entrevistada, o sentimento pode ser construído, mas é diferente quando a pessoa nasce com esse sentimento. Há aí uma percepção de naturalidade do sentimento; de algo que vem de dentro. Para ela, é preciso que assim seja, pois, se a menina não passa emoção, não passa nada eles vão olhar o que? $O$ físico. Essa noção de naturalidade do sentimento no balé clássico é recorrente entre as entrevistadas, fazendo parte de um repertório comum entre as 
bailarinas. Como analisa Le Breton ${ }^{13}$, percebemos nossos sentimentos como sendo "naturais", todavia, eles são sempre construídos socialmente. Segundo o autor, "para que um sentimento (ou emoção) seja experimentado ou exprimido pelo indivíduo, ele deve pertencer, de uma forma ou de outra, ao repertório cultural do seu grupo", que aí lhe fornece um sentido, como acontece no grupo das bailarinas.

Esse "lado artístico" foi o mais complexo de apreensão, pois está em um nível profundo de subjetividade, como se fosse algo muito singular porque, segundo as entrevistadas, para cada pessoa será de uma maneira; uma vivência transcendental para elas, não acontecendo no plano objetivo do aprendizado e sim no sensível, como algo "além" do corpo físico, no sentido do orgânico. Nesse aspecto, corpo e pessoa voltam a se separar, como se o sensível não estivesse no corpo; não fosse dado por meio do corpo, estando acima, "além". Ancorado a esta ideia, a plenitude cênica para algumas delas só acontece no palco, quando estão "dentro da caixa” com três lados, uma plateia, um cenário, um figurino e simplesmente dançam.

Nessa percepção do momento em que "simplesmente dançam", a emoção e os sentimentos aparecem como características especiais das bailarinas, algo inato. Esse “inato" é assim percebido em meio ao processo de se "fazer bailarina clássica", mais precisamente, na experiência da dança, da apresentação no palco, da relação com a plateia, a partir de um cenário e um figurino, da emoção experimentada nesse momento, que aparece como algo singular, de cada um. Como desenvolve LE BRETON ${ }^{13}$, “a emoção experimentada traduz a significação conferida pelo indivíduo às circunstâncias que nele ressoam. É uma atividade de conhecimento, uma construçáo social e cultural, a qual se torna um fato pessoal mediante o estilo particular do indivíduo". Le BRETON ${ }^{13}$ desenvolve a ideia de que as emoçôes não são estados absolutos ou naturais. Embora sejam sentidas na experiência singular, são traduzidas, até mesmo como "inatas", conforme valores e contextos sociais específicos que ancoram essas experiências.

A partir dessa percepção das entrevistadas do "lado artístico" da bailarina clássica, como algo inato, posto que mais sensível e transcendente, tem-se o corpo que materializa essa transcendência e que se define por uma tríade, a "tríade do corpo". São Três elementos fundamentais que compóem o corpo da bailarina, conforme pudemos apreender das entrevistas, e para o qual há uma ordem lógica de aquisição de cada esfera, segundo a percepção das bailarinas (FIGURA 1).

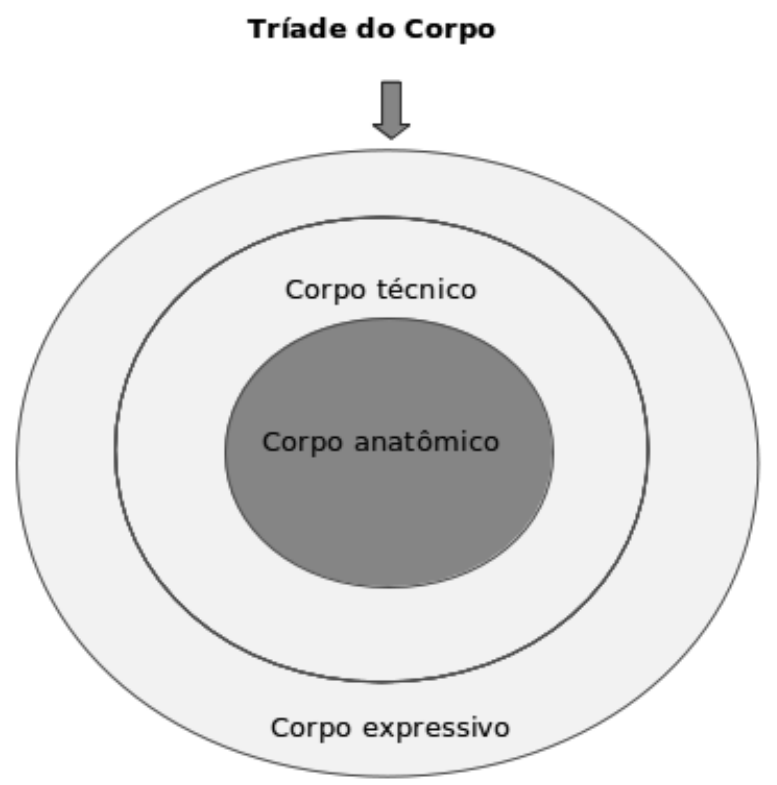

FIGURA 1 - Tríade do corpo da bailarina: anatomia, técnica e expressão.

A ideia das esferas interpostas é visualizar a lógica da construção desse corpo e, ao mesmo tempo, apreender a expansão desse corpo. A primeira esfera refere-se ao corpo físico/anatômico; a segunda, circundando a primeira, ao corpo técnico e a terceira esfera, em volta da segunda, o expressivo. $\mathrm{O}$ centro da esfera, a anatomia, é imprescindível para as outras; a técnica, por sua vez, é sua subordinada. A esfera expressiva do corpo, de acordo com os relatos, acontece, principalmente, no palco, quando as bailarinas 
devem representar. É no palco que a bailarina parece "não ter um corpo", não senti-lo, uma vez que atinge a transcendência, parecendo a ela estar além do próprio corpo; transcendendo-o, uma vez que não se percebe a ele subjugada, tamanha a incorporação da técnica que já maneja, e da força da representação cênica; da expressividade do corpo, no espetáculo da dança.

No referente às esferas que compóe a tríade do corpo, a primeira esfera está no âmbito da condição do sujeito, que deve estar em conformidade com a determinação da cultura corporal do balé; já a técnica está no nível do que poderíamos chamar de "vontade", ou seja, daquilo que o sujeito intencionalmente almeja e se dedica, através do trabalho, com fins de aquisição da técnica; e a expressão, no âmbito da subjetividade, da "coisa como dada", da transcendência artística, do sujeito fora de seu próprio corpo.

\section{Eficiência e funcionalidade corporal}

Um corpo magro e sem curvas, imposto pelo balé, não deve gerar uma ineficácia física na bailarina. Há a necessidade de um rendimento satisfatório da pessoa que dança. Ela deve suportar uma intensidade elevada de treino e seu corpo tem que estar esteticamente adequado, mas com um nível considerado ótimo de flexibilidade e força muscular, tudo avaliado e medido. Uma das entrevistadas aponta este aspecto.

B4: Físico que tenha facilidade de flexibilidade, evidentemente uma companhia, por exemplo, vai definir a altura das bailarinas, que o corpo de baile vai ter, então, eles vão medir até a possibilidade de crescimento, a possibilidade de desenvolvimento muscular, o tipo físico já demonstra se é uma musculatura, alonga; tendência a alongamento ou se é uma musculatura mais enrijecida. Pés, linhas de pés, linhas; eles medem tudo.

Nessas condiçôes, ela terá a beleza da bailarina, que deve assemelhar-se a uma Sílfide, mas com uma força que permitirá a execução de movimentos complexos em espetáculos longos, os quais podem levá-la à exaustão. A entrevistada B3 menciona o fato:

Tem que ser magro, mas também não pode ser uma magra anoréxica que não vai ter força pra fazer nada, não aguentar fazer um espetáculo, um espetáculo completo de uma hora e meia, não vai aguentar se for magra sem força, sem músculo.

Técnica e força são elementos importantes, como mostra outra entrevistada,

B2: Tem gente que tem mais facilidade para tudo, e ai é só acrescentar conhecimento para a pessoa, e acrescentar força e técnica.
A função deve ser mantida e garantida ao longo da vida da bailarina, preservar seu corpo das agruras do esforço físico exaustivo é um desafio como aponta a bailarina:

B5: Como é que eu utilizo esse corpo durante 10, 15, 20 anos, 30 anos, 40 anos sem acabar com meu menisco. Comprometer as articulaçôes, lesôes graves, rompimentos de tendão e enfim. Como é que eu faço isso?

Segundo as percepçóes das entrevistadas, a funcionalidade da bailarina deve ser mantida mesmo com a exigência de uma magreza extrema. Esse ideal de corpo nem sempre é o real; o que a bailarina possui. Assim, muitas delas devem construir esse corpo e mantê-lo, caso queiram seguir com o balé clássico, profissionalmente, pois esse ideal é o produto requerido pelas empresas de balé: um corpo magro, forte e flexível. Esse é o padrão que garantirá, por meio do esforço e treinamento sistemático, a eficácia, logo, a funcionalidade esperada da bailarina clássica. Como destaca Vigarello ${ }^{14}$, ao discorrer sobre os programas e métodos de treinamento para práticas físicas, no século XX, há nesses programas "uma visão sempre mais técnica e mecânica do movimento, uma visão sempre mais rigorosa e ordenada do movimento" (p.198). Conforme aponta, é o "triunfo do exercício 'construído', o de movimentos sistematizados, mecânicos e precisos, controlados com o único objetivo de aumentar os recursos físicos: neles, o corpo seria educado de acordo com um código analítico da progressão, músculo após músculo, parte após parte" (p.199). Isso parece ainda mais verdadeiro no balé clássico, no qual o corpo também é pensado como ferramenta para o trabalho da dança.

B5: Um corpo que tá sendo treinado para ser utilizado como uma ferramenta de trabalho. Uma ferramenta, porque o nosso corpo ele é uma ferramenta em prol da dança.

\section{Moralidade da dedicação e imitação prestigiosa}

A bailarina clássica parece viver numa eterna dedicação ao balé. Esse fato compóe necessariamente a identidade da pessoa que entra nesse universo, surgindo então, como algo moral; o valor dado a essa atitude aparece como um dever arraigado à cultura do balé. Para se alcançar a perfeição é importante persistir e nunca se contentar com o nível alcançado, pois há sempre algo para ser melhorado. É a legitimidade do treinamento, aponta VIGARELLO ${ }^{14}$. Esta legitimidade, aponta o autor, "vai se impor no 
século XX, como uma organização sempre mais exigente” (p.197). As entrevistadas também destacam esse aspecto da exigência e do trabalho árduo sobre o corpo. Para B1:

Que é mais bonito, que parece que o joelho que estica mais, o pé que estica mais, a perna que levanta mais é o ideal de corpo.

Outra entrevistada, B2, menciona:

Um corpo que eu conseguisse executar toda a técnica do balé, que é uma técnica dura, que exige um esforço, um trabalho árduo de bailarina e horas de treino, mas um corpo que eu conseguia executar com a máxima limpeza os movimentos de técnica do balé. Assim que o joelho esticado, então, eu tentava construir esse joelho que se esticava ao ponto de que deveria esticar; aquele, o colo de pé que se fala tanto, eu não tinha esse colo de pé e tentava construir ao máximo esse colo de pé com exercício, com até torturas.

Dedicar-se implica não poupar sacrifícios físicos e mentais para se obter determinados resultados e essa dedicação é legitimada pela paixão atribuída ao balé.

A entrevistada $\mathbf{B} \mathbf{6}$ traz a seguinte ideia:

Eu sou, eu sempre fui e ainda até falo hoje com minhas alunas que no balé você não precisa ter tudo, você tendo a paixão pelo que você faz acho que em qualquer profissão você se entrega por inteira, então eu creio que você se dedicar, correr atrás mesmo com as dificuldades, eu não tinha nada.

A acirrada disputa entre as bailarinas nos festivais também as conduz a uma busca incessante pela perfeição. Entretanto, a cobrança não acontece somente nessas competiçóes, já que as bailarinas cobram a si mesmas, lutando, se necessário, contra a sua constituição física e características pessoais para atingir um determinado padrão, um modelo externo. Isso faz parte da cultura do balé.

B3: Sim, eu acho que sim, porque você vai muito, eu vou muito em festival ai você assiste muito, você vê muito aquele corpo bonito, trabalhado.

Fazendo parte da cultura do balé, a imitação do comportamento, dos atos e performances bem sucedidas servem de inspiração às bailarinas, ao esforço e dedicação empreendidos. Um conceito importante para pensar essa questão é o de "imitação prestigiosa”, de Mauss ${ }^{11}$. Segundo o autor, a imitação prestigiosa refere-se à imitação de um ato por uma pessoa que imita aquele que ela admira. Assim, argumenta o autor, é o prestígio da pessoa que torna o ato autorizado àquele que imita, como ocorre no balé clássico. Uma das bailarinas traz essa ideia ao comentar sobre um determinado filme.
B4: Tem um filme muito legal se você quiser ver que é sobre a escola Russa com a Grace Kelly narrando. E o universo que é narrado é muito claro, da maneira como ele é filmado e dirigido você entende bem essa, ideia toda de medir tudo. Eles medem tudo.

\section{Profissionalização no balé}

O balé clássico tem "status" de profissãoj. Existem companhias que produzem e contratam profissionais de balé e são essas mesmas companhias que padronizam seus bailarinos e contratam o perfil que consideram o ideal para compor o seu elenco. Como profissão, o balé requer esforço e disciplina dos seus trabalhadores e, mesmo não sendo remunerada, a bailarina segue disciplinada na sua formação, ainda que demore anos para que consiga adentrar em uma companhia de dança.

B4: Profissionalmente você vai ser obrigado a estar inserido no universo de dança, mas pra você entender o que é pedido pra você, mesmo como diletante, que você não tem um pouco de informação que seja, informação também diletante, curiosidade; modifica a compreensão do que é pedido em sala de aula , senão você fica boiando mesmo, você vai entender como uma repetição simples que não é uma repetição simples, uma repetição de dança, de movimento para arte não uma repetição de movimento para ginástica, por exemplo.

Se a bailarina não segue a carreira dançando e se não desiste, muitas vezes opta pela carreira de professora ou de "maître" de balé. Uma das entrevistadas voltou para o balé, mas agora como professora e relatou a sua vontade de incentivar as meninas que, de acordo com ela, têm talento; ela visualiza o balé como uma profissão como qualquer outra, mas percebe que aqui no Brasil os pais colocam suas filhas nas escolas de dança não com o propósito de seguir a profissão, o que ela aponta como uma dificuldade.

B6: É muito difícil, além de tudo eu acho que escola do jeito que é aqui, é paga, então, você lidar com vários tipos de crianças e vários tipos de pais, que, às vezes, os piores são os pais, às vezes, você vê que a menina tem talento, mas se você da uma chamada de atenção, ou você vai pegar muito no pé dessa criança, eles [os pais] já [dizem] quero que ela siga outra profissão.

É interessante notar que, no caso do balé, a profissão se confunde com paixão - o que também legitima a dedicação extrema das bailarinas e parece justificar sua permanência no balé. Assim, mesmo havendo um discurso racional sobre o balé como uma profissão, há, 
ao mesmo tempo, um discurso "apaixonado" que legitima a persistência e continuação dos estudos de balé.

Quando a profissionalização não acontece, aparece a frustração, sentimento declarado num tom reflexivo. Mesmo decepcionada, a bailarina, apaixonada, encontra uma saída para seguir com o balé. $O$ prazer em dançar e até mesmo de ensinar outras pessoas e vê-las profissionalizando-se parece relativizar a frustração que se torna mais uma vivência entre tantas outras possíveis do sujeito, sem, necessariamente, paralisá-lo, uma vez que o momento da dança, da apresentação, é visto como transcendente ao próprio corpo e às dificuldades encontradas.

B3: Eu me sinto bem, às vezes, a gente se sente mal fora do balé, bate um momento de depressão - 'pô eu queria tá melhor no balé - sempre pensando em balé, lógico - eu queria tá já na Cia "x", eu queria ser a primeira bailarina - e aí você fica triste, fico meio deprimida, mas aí eu vou pra aula, eu faço aula, a gente começa a ensaiar e eu vou dançar, eu me sinto bem, eu me sinto muito feliz, nada me faz ficar triste dançando.
Assim, voltamos às unidades de sentido mencionadas no início deste texto, sendo a tríade do corpo a que se aproxima da "essência" do fenômeno, a percepção pela bailarina do corpo ideal no balé clássico. Essa unidade (físico/ anatômico, técnica, expressividade) foi recorrente em todas as entrevistas; e a base, o centro físicol anatômico aparece como o eixo essencial desse ideal, sem ele ficou claro que a bailarina não se fixa no universo profissional e talvez náo alcance a técnica requerida. As demais unidades que compóem a "essência” surgem para compreendermos como esse ideal fora (ou é) consolidado; como ele é legitimado nesse universo das bailarinas. Por mais que tenhamos dois verbos para alcançarmos as reduçóes (identificar e compreender), fica nítido que os mesmos acontecem de forma integrada. Esquematizamos essa ideia sobre as unidades de sentido. Em nosso desenho, o círculo que envolve as unidades representa o fenômeno estudado, o corpo da bailarina clássica. Abaixo, nosso diagrama (FIGURA 2):

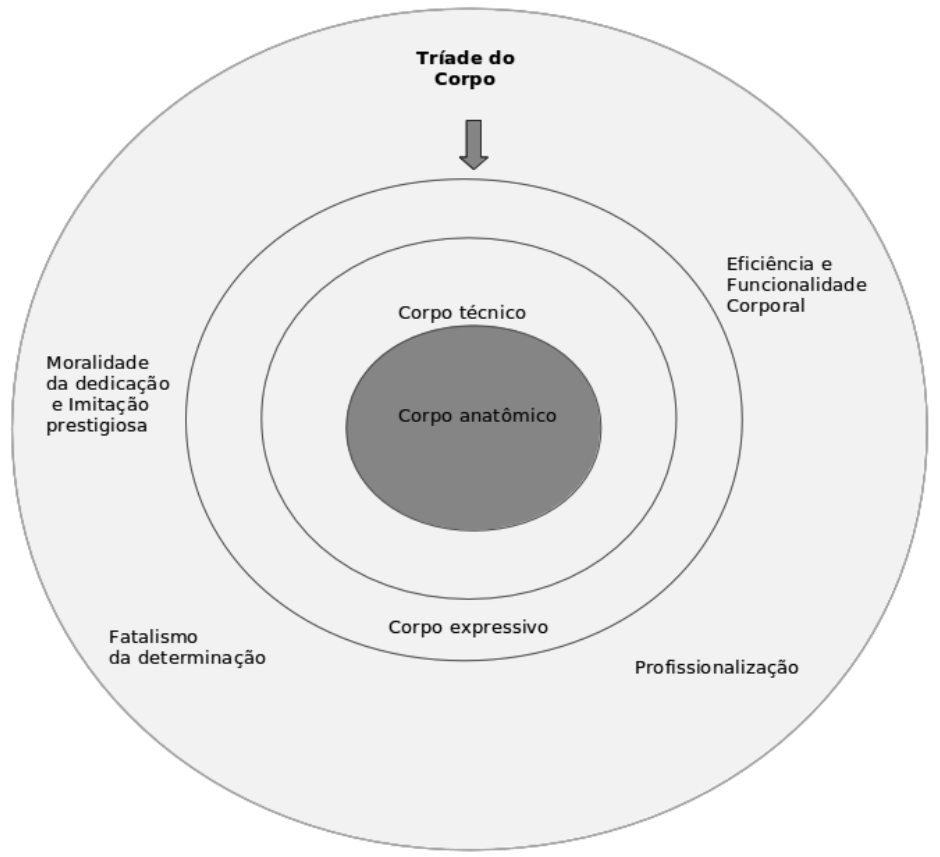

FIGURA 2 - O corpo da bailarina clássica: unidades de sentido.

Esse trabalho nos permitiu compreender que o corpo demandado da bailarina está na inter-relação de vários elementos: físico/anatômico; um corpo magro; longilíneo, flexível; com uma estrutura anatômica que propicie o "en dehors" (rotação externa dos membros inferiores); um belo colo de pé, o arqueamento gerado quando a bailarina faz uma ampla flexão plantar ao subir nas pontas, sendo desejável também uma hiperextensão de membros inferiores gerando assim uma estética específica das bailarinas.

As unidades de sentido, como o próprio nome sugere, trouxeram o sentido desse "ideal", referido àquilo que aparece como inevitável e determinado culturalmente; o mesmo segue reconstruindo-se e se reatualizando à medida que os grandes nomes do balé vão mostrando quem e de que maneira 
selecionam para seus trabalhos. O ideal aqui significa o corpo necessário para se dedicar ao balé clássico.

Determinados elementos presentes nas falas das entrevistadas permitiram-nos apreender aquilo que parece ser constitutivo de um ideal de corpo requerido pelo balé clássico e que está centrado nas produçóes feitas pelas grandes companhias de balé. $\mathrm{Na}$ compreensão das entrevistadas, o corpo desejado, a anatomia "perfeita", pode ser tanto algo inato à pessoa, quanto construído com muito esforço e dedicação, o que impóe à bailarina que a prática e o aprendizado nunca cessem. Ao mesmo tempo, a construção corporal vai sendo conformada em três partes interpostas e extremamente necessárias para o alcance do auge na profissão de bailarina clássica.

Esse corpo "perfeito" deve ser magro, mas há o discurso da magreza saudável, pois a eficácia da bailarina não pode ser comprometida; um corpo funcional para dançar é também essencial. Essa busca pela "perfeição" parece ser necessária para a profissionalização, porém, mesmo aquelas que não chegam a essa etapa, parecem ser cobradas, pois há a ideia, baseada numa construção social a esse respeito, de que a bailarina "tem que ter" determinado corpo.

O "voltar às coisas mesmas", postura fenomenológica, nos conduziu também a pensar sobre o corpo humano e, com as unidades de sentido, refletir sobre o corpo em outras situaçóes; em práticas de atividade física, no esporte, nessa ou em outras culturas. $\mathrm{O}$ corpo humano constitui e é constitutivo de significados atrelados à vivência do sujeito; à sua experiência. Essas experiências constituem o estoque de conhecimentos à mão ${ }^{11}$ do sujeito, que atuam tanto para a interpretaçáo da experiência atual, como para as antecipaçóes e expectativas em relação ao futuro, como no balé, no referente à experiência atual do corpo real e às expectativas e antecipaçóes que motivam o trabalho para o alcance do corpo ideal, ambos permeados pela plenitude cênica da apresentaçáo no palco.

A exigência de um corpo ideal é um assunto discutido em vários campos de conhecimento; no campo onde estáo alocados os profissionais da educação física e, recentemente, naqueles das ciências da atividade física e esportes, essa é uma discussão necessária, já que o trabalho de intervenção desses profissionais também é informado por determinados padróes de beleza e de corpo saudável.

Esta pesquisa permitiu a reflexão sobre a construçáo social de padróes corporais do balé clássico. Partimos da esfera do subjetivo, das vivências singulares, para refletirmos sobre o social, sem a intenção de generalizaçáo, pois nossos resultados compóem um cenário de um determinado tempo e espaço, que circunscreve a dança, o balé clássico.

Observamos que esta dança enlaça a bailarina na sua totalidade, em seus aspectos técnicos, físicos e emocionais. Como destaca ViannA ${ }^{15}$, dançar é um estado de plenitude, "o que é dançado é dançado por alguém que vive intensamente aquele movimento, aquele gesto, e por isso consegue expressá-lo plenamente" (p.103). No caso da bailarina clássica, isto pode ser percebido especialmente no momento do espetáculo, da expressão cênica, do corpo em foco, corpo anatômico, técnico e cênico.

\section{Notas}

a. BARREIrA ${ }^{5}$, menciona que utilizar a fenomenologia para estudar questôes voltadas à prática de atividade física - e nós diríamos também relacionadas ao corpo - significa empreender um esforço investigativo profundo, que não se contenta com a superficialidade de respostas verbais que repetem aquilo que é convencional, ou usual na área (p.7). O autor ainda sugere que para utilizar a fenomenologia clássica devemos recorrer a teóricos como Ales Bello, uma autora contemporânea que estuda o fundador da fenomenologia, Husserl, em especial, o método fenomenológico, além do estudo de discípulos do autor, dentre os quais; Edith Stein. Apoiado nesses autores, Barreira frisa que assim seria possível fazer uma descrição rigorosa do fenômeno bem como uma adequada redução eidética.

b. Essência é o que faz uma coisa ser o que ela é.

c. Foram entrevistadas sete bailarinas que estavam, no momento da entrevista, atuando ou como artistas ou na formação de bailarinas. Ao iniciarmos a entrevista, as bailarinas foram informadas dos objetivos da pesquisa e de que as suas identidades seriam preservadas; ao mesmo tempo as suas concordâncias em participar das entrevistas foram registradas em papel precedendo a gravação das entrevistas. Duas questôes centrais propostas às bailarinas nortearam as entrevistas: Você acha que existe um ideal de corpo no balé? Na sua vivência como bailarina, foi sendo sugerido a você um ideal de corpo? As entrevistadas não pertenciam a um mesmo grupo de dança; a seleção foi direcionada pela experiência de quem entrevistou, que procurou mulheres ainda na prática do balé e que já vivenciaram seja em seus alunos ou por si mesma a vida profissional ou diletante do balé. 
d. De acordo com MinAYo ${ }^{16}$ a entrevista semiestruturada pode ser compreendida como a união entre a entrevista estruturada, mais dirigida - com perguntas previamente formuladas - e a entrevista aberta na qual o informante aborda o tema de maneira livre; já a entrevista em profundidade, conforme a autora, seria um "dialogo intensamente correspondido entre entrevistador e informante", assim existe a possibilidade de acessar a experiência do vivido (p.58-9).

e. Não é nossa intençáo fazer uma explicaçáo acurada do método fenomenológico, mas tentaremos expor o processo pelo qual passamos para desenvolver essa pesquisa.

f. De acordo com $\mathrm{Goto}^{8}$ a consciência transcendental "é a própria vida humana pura com o conjunto de atos vividos e objetos intencionais" (p.78)

g. A redução fenomenológica, que conduz à visualização das US, é, segundo Husserl, a responsável pelo acesso ao modo de consideração transcendental, ou seja, o retorno à consciência. Para o filósofo, é a redução fenomenológica que permite aos objetos que se revelem em sua constituição ${ }^{7}$ (p.19).

h. Tutu é, se for o Tutu romântico, um tipo de vestido cuja saia tem um formato de repolho e o comprimento da saia vai até os joelhos ou abaixo deles; há também o Tutu cuja saia tem um formato de prato e o quadril e as pernas ficam visíveis.

i. Como desenvolve MAuss ${ }^{11}$, as técnicas são sempre adquiridas e não "naturais", assim como as noçóes de corpo e pessoa são construçôes sociais e históricas.

j. Como desenvolve Adam e Herzlich ${ }^{17}$, "de modo geral, os 'profissionais' distinguem-se dos outros ofícios por um alto nível de formação teórica e especializada e uma 'orientação de serviço' para a população à qual corresponde a ideia de vocação" (p.38). No caso do balé clássico, poderíamos pensar no serviço da expressão artística.

\begin{abstract}
The construction of the ideal body in classical ballet: a phenomenological investigation

The aim of this study was to identify and understand by perspective of ballerinas surveyed the ideal body demanded by the practice of ballet. Therefore, we chose a epistemological orientation supported by the phenomenology of Edmund Husserl and authors in tune with phenomenological approach. As a research technique were performed semi-structured interviews in-depth. What is common in the speech of the dancers is a reference to an ideal body that is centered in the productions made by major ballet companies. In these perceptions, the ideal and desired body of classical ballet can be both innate to the person how constructed and transformed with much effort and dedication.
\end{abstract}

KeY WoRDS: Experience; Body; Phenomenon; Ballet; Body expression.

\title{
Referências
}

1. Caminada E. História da dança: evolução cultural. Rio de Janeiro: Sprint; 1999.

2. Moura, KCF. Essas bailarinas fantásticas e seus corpos maravilhosos: existe um corpo ideal para dança? [dissertação]. Campinas (SP): Universidade Estadual de Campinas, Faculdade de Educação; 2001.

3. Moreira WW, organizador. Século XXI: a era do corpo ativo. Campinas: Papirus; 2006.

4. Ales Bello Â. Introdução à fenomenologia. Garcia JT, Miguel Mahfoud M, tradutores. Bauru: Edusc; 2006.

5. Barreira CRA. A fenomenologia como ciência das dimensóes existenciais da atividade física: uma abordagem em psicologia do esporte. XIV Encontro Nacional da ABRAPSO; 2007; Rio de Janeiro, BR. Rio de Janeiro: ABRAPSO; 2007.

6. Barreira CRA, Ranieri LP, Carbinatto MV. O mundo circundante na atividade física: uma investigaçáo fenomenológica.IV Congresso Internacional de Psicologia eX Semana de Psicologia da UEM; 2009; Maringá, BR. Maringá: UEM, 2009. p.1-17.

7. Galeffi DA. O que é isto: a fenomenologia de Husserl? Ideação. 2000;5:13-36. Disponível em: http://www.uefs.br/ nef/dante5.pdf.

8. Goto TA. Introdução à psicologia fenomenológica: a nova psicologia de Edmund Husserl. São Paulo: Paulus; 2008.

9. Husserl E. A Ideia da fenomenologia. Mourão A, tradutor. Rio de Janeiro: Ediçóes 70; 1990. 
10. Tourinho CDC. O Transcendente e suas variações na fenomenologia transcendental de Edmund Husserl. Prometeus. 2012;5:27-41. Disponível em: http://200.17.141.110/periodicos/prometeus/9/2.pdf.

11. Mauss M. Sociologia e antropologia. São Paulo: Cosac Naif; 2003.

12. Le Breton D. Adeus ao corpo: antropologia e sociedade. Campinas: Papirus; 2007.

13. Le Breton D. As paixôes ordinárias: antropologia das emoçôes. Petrópolis: Vozes; 2009.

14. Vigarello G. Treinar. In: Corbain A, Courtine J-J, Vigarello G, organizadores. História do corpo: as mutações do olhar: o século XX. Petrópolis: Vozes; 2009.

15. Vianna K. A dança. São Paulo: Siciliano; 1990.

16. Minayo MCS, organizadora. Pesquisa social: teoria, método e criatividade. 21a ed. Petrópolis: Vozes; 2002.

17. Adam P, Herzlich C. Sociologia da doença e da medicina. Bauru: EDUC; 2001.

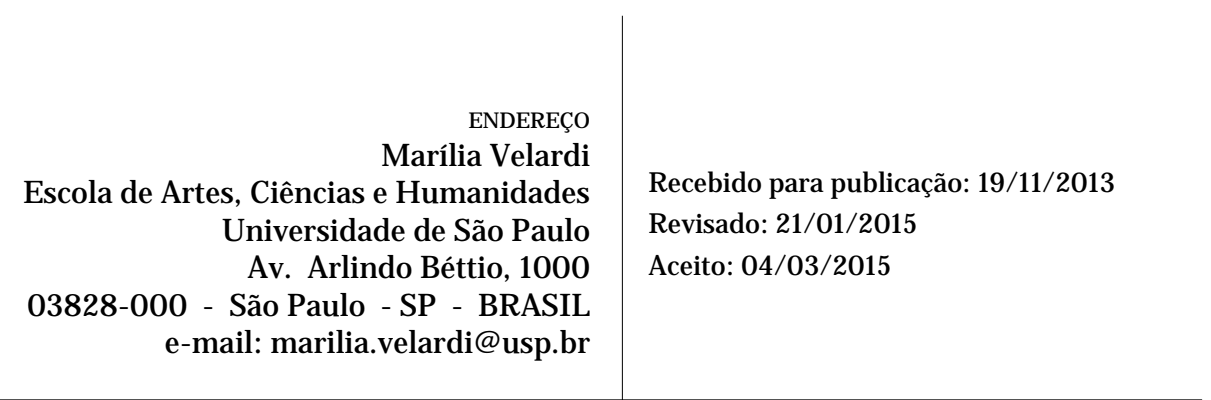

